\title{
KESESUAIAN PENERAPAN STANDAR PELAYANAN KEFARMASIAN DI APOTEK MILIK BUMN WILAYAH KOTA MANADO
}

\author{
Nindi Septyawati Badu'), Widya Astuty Lolo ${ }^{1)}$, Imam Jayanto ${ }^{1)}$ \\ ${ }^{1)}$ Program Studi Farmasi FMIPA UNSRAT Manado, 95115
}

\begin{abstract}
The application of pharmaceutical service standards in pharmacies in general is not in accordance with the Decree of the Minister of Health of the Republic of Indonesia at Year of 2016 concerning the Pharmaceutical Service Standards at the Pharmacy, which stipulates that all pharmaceutical personnel in carrying out their professional duties at pharmacies refer to these standards. This study aims to determine the suitability of the management of pharmacies owned by state-owned companies in the City of Manado with pharmaceutical service standards at the Pharmacy according to the Decree of the Minister of Health No. 73 of 2016. This type of research is a descriptive study. Data was collected by conducting direct observations accompanied by filling in questionnaires at 5 state-owned pharmacies in the Manado City Region. Based on the results of this study it is known that all pharmacies have met the standards of aspects of supply management, resources and the availability of facilities and infrastructure that are included in the good category. While the aspect of prescription services included in the good category as many as 2 pharmacies, with an average value for prescription services for 2 pharmacies is $72.72 \%$.
\end{abstract}

Keywoard : Pharmacy, Pharmacist, Pharmaceutical Service Standards.

\begin{abstract}
ABSTRAK
Penerapan standar pelayanan kefarmasian di apotek pada umumnya belum sesuai dengan Peratuuran Menteri Kesehatan Republik Indonesia Tahun 2016 tentang Standar Pelayanan Kefarmasian di Apotek, yang menetapkan bahwa semua tenaga kefarmasian dalam melaksanakan tugas profesinya di apotek agar mengacu pada standar tersebut. Penelitian ini bertujuan untuk mengetahui Kesesuaian Pengelolaan Apotek milik BUMN Wilayah Kota Manado dengan Standar Pelayanan Kefarmasian di Apotek menurut Peraturan Menteri Kesehatan Republik Indonesia No. 73 Tahun 2016. Jenis penelitian ini merupakan penelitian deskriptif. Data dikumpulkan dengan cara melakukan observasi langsung disertai dengan pengisian kuesioner pada 5 apotek BUMN di Wilayah Kota Manado. Berdasarkan hasil penelitian ini diketahui bahwa seluruh apotek telah memenuhi standar dari aspek pengelolaan perbekalan, sumber daya dan ketersediaan fasilitas sarana dan prasarana yang termasuk dalam kategori baik. Sedangkan dari aspek pelayanan resep yang termasuk dalam kategori baik sebanyak 2 apotek, dengan nilai rata-rata untuk pelayanan resep 2 apotek adalah $72,72 \%$.
\end{abstract}

Kata Kunci : Apotek, Apoteker, Standar Pelayanan Kefarmasian. 


\section{PENDAHULUAN}

Apotek adalah sarana pelayanan kefarmasian tempat dilakukan praktik kefarmasian oleh apoteker (Permenkes RI, 2016). Perkembangan apotek ini sangat ditentukan oleh pengelolaan sumber daya dan pelayanan di apotek tersebut. Penerapan Standar Pelayanan Kefarmasian sangat diperlukan dalam menjalankan suatu apotek. Suatu apotek tidak menggunakan standar pelayanan farmasi dalam menjalankan apotek maka tidak akan tercapai derajat kesehatan yang optimal bagi masyarakat (Hartini dan Sulasmono, 2006).

Peraturan yang berkaitan erat dengan Standar Pelayanan Kefarmasian di Apotek yang berlaku di Indonesia saat ini adalah Permenkes Nomor 73 Tahun 2016. Pengaturan standar pelayanan kefarmasian di apotek bertujuan untuk meningkatkan mutu pelayanan kefarmasian, menjamin kepastian hukum bagi tenaga kefarmasian dan melindungi pasien dan masyarakat dari penggunaan obat yang tidak rasional dalam rangka keselamatan pasien (patient safety).

Pelayanan kefarmasian (Pharmaceutical care) merupakan salah satu sub sistem pelayanan kesehatan yang berorientasi pada pasien. Pelayanan kefarmasian ini mengarahkan pasien tentang kebiasaan/pola hidup yang mendukung tercapainya keberhasilan pengobatan yang harus dijalani pasien, memonitor hasil pengobatan dan bekerja sama dengan profesi lainnya untuk mencapai kualitas hidup yang optimal bagi pasien (Ginting,2009). Untuk menjamin mutu pelayanan kefarmasian di apotek, harus dilakukan kesesuaian standar pelayananan kefarmasian.

\section{METODOLOGI PENELITIAN}

Waktu dan Tempat Penelitian

Penelitian dilaksanakan pada bulan Mei-Juni 2019 di lima apotek milik BUMN yang berada di Kota Manado.

\section{Jenis Penelitian}

Jenis penelitian ini merupakan penelitian deskriptif dengan cara melakukan observasi langsung disertai dengan pengisian kuesioner pada 5 apotek milik BUMN di kota Manado. Penelitian deskriptif merupakan penelitian yang dilakukan dengan tujuan utama untuk membuat gambaran atau deskripsi tentang suatu keadaan secara obyektif (Notoatmodjo, 2002).

\section{Pengumpulan Data}

a. Deskripsi

Analisis data ditulis berdasarkan pendekatan deskriptif yang didasarkan pada Peraturan Menteri Kesehatan RI Nomor 73 Tahun 2016. Data yang dikumpulkan mengenai data apotek, data apoteker, sumber daya kefarmasian dan pelayanan kefarmasian.

b. Skoring

Kategori pengelolaan sumber daya dan pelayanan digolongkan menjadi tiga kategori yaitu Baik bila nilai skor yang diperoleh $>75 \%$, Cukup bila nilai skor yang diperoleh $60 \%-75 \%$ dan Kurang, bila nilai skor yang diperoleh $<60 \%$ (Arikunto, 2001). 
HASIL DAN PEMBAHASAN

Demografi Apotek

Tabel 1. Data Demografi Apotek

\begin{tabular}{lll}
\hline Keterangan & $\begin{array}{l}\text { Jumlah } \\
\text { Apotek }\end{array}$ & Persentase \\
&
\end{tabular}

Lama berdiri

apotek

\begin{tabular}{lll}
$<5$ tahun & 3 & $60 \%$ \\
$\geq 5$ tahun & 2 & $40 \%$ \\
\hline Lama jam buka & & \\
$<24$ jam & 3 & $60 \%$ \\
24 jam & 2 & $40 \%$ \\
\hline
\end{tabular}

Omzet penjualan

rata-rata tiap hari

\begin{tabular}{lll}
$<\operatorname{Rp} 2.000 .000$ & 3 & $60 \%$ \\
$\geq \operatorname{Rp} 2.000 .000$ & 2 & $40 \%$ \\
\hline Jumlah resep rata- & & \\
rata per hari & & \\
$<10$ lembar & 3 & $60 \%$ \\
$\geq 10$ lembar & 2 & $40 \%$
\end{tabular}

Jumlah Asisten

Apoteker

$<2$ orang $\quad 3 \quad 60 \%$

3-5 orang $\quad 2 \quad 40 \%$

Lokasi apotek ini

menjadi satu

dengan unit usaha

lain

$\begin{array}{lll}\text { Ya } & 5 & 100 \%\end{array}$

Tidak

Apotek menjadi

satu lokasi dengan

tempat praktek

dokter

\begin{tabular}{lll} 
Ya & 3 & $60 \%$ \\
Tidak & 2 & $40 \%$ \\
\hline
\end{tabular}

Jumlah dokter

yang praktek

bersama

$\begin{array}{llc}1-3 \text { orang } & 1 & 20 \% \\ 4-5 \text { orang } & - & -\end{array}$

>5 orang $\quad 2 \quad 40 \%$

Apotek dikategorikan menjadi 2 kategori berdasarkan lama berdiri apotek yaitu apotek yang lama berdirinya kurang dari 5 tahun sebesar $60 \%$ dan apotek yang lama berdirinya lebih dari 5 tahun sebesar $40 \%$. Untuk apotek yang berdiri $<5$ tahun omzet penjualannya lebih sedikit dan resep tiap hari <10 lembar dikarenakan apotek ini kurang dikenali oleh masyarakat sehingga apotek belum memiliki banyak pelanggan dibandingkan dengan apotek yang berdiri $\geq 5$ tahun. Apotek yang telah berdiri $\geq 5$ tahun lebih unggul dari segi omzet yang berbanding lurus dengan jumlah resep yang lebih banyak. Jumlah pelanggan yang banyak juga dipengaruhi karena apotek telah bekerja sama dengan beberapa dokter praktek, sehingga menunjang naiknya peningkatan omzet. Untuk memberikan pelayanan kefarmasian yang optimal bagi masyarakat, maka apotek BUMN berupaya untuk menerapkan jam buka apotek selama 24 jam. Berdasarkan hasil yang diperoleh terdapat 2 apotek telah memenuhi target tersebut, sementara 3 apotek lainnya beroperasi dengan jam buka $<15$ jam.

Hasil penelitian menunjukan bahwa dari 5 apotek BUMN, terdapat 3 apotek diantaranya yang memiliki asisten $<2$ orang dan 2 apotek memiliki asisten apoteker $\geq 5$ orang. Jumlah asisten apoteker yang semakin banyak akan memberikan pelayanan yang optimal sehingga pasien tidak menunggu terlalu lama untuk mendapatkan pelayanan lebih efektif dan efisen bagi masyarakat.

Apotek yang digunakan sebagai tempat praktek dokter sebanyak 3 apotek dengan persentase (60\%). Adanya praktek dokter di apotek dapat menambah omzet penjualan karena jumlah resep yang masuk di apotek 
bertambah dengan adanya praktek dokter di apotek tersebut. Jumlah dokter praktek bersama berbeda-beda, 1 apotek memiliki jumlah dokter praktek bersama 1-3 orang dengan persentase $20 \%$, sedangkan 2 apotek memiliki jumlah dokter praktek bersama $\geq 5$ orang dengan persentase $40 \%$.

\section{Demografi Apoteker}

Tabel 2. Data Demografi Apoteker Pengelola Apotek (APA)

\begin{tabular}{lcc}
\hline Keterangan & $\begin{array}{c}\text { Jumlah } \\
\text { Apotek }\end{array}$ & Persentase \\
\hline Pengalaman & & \\
Apoteker sebagai & & \\
APA & & \\
$<$ 1 tahun & - & - \\
1-5 tahun & 4 & $80 \%$ \\
6-10 tahun & 1 & $20 \%$ \\
$>10$ tahun & - & - \\
\hline
\end{tabular}

Frekuensi

kehadiran

Apoteker di apotek

Seminggu 1-2 kali

Seminggu 3-5 kali

$120 \%$

Tiap hari

$4 \quad 80 \%$

Apoteker tiap kali

datang ke apotek

selama

$<1$ jam

$120 \%$

1-3 jam

3-5 jam

$>5$ jam

Apakah memiliki

apoteker

pendamping?

\begin{tabular}{lll} 
Ya & 2 & $40 \%$ \\
Tidak & 3 & $60 \%$ \\
\hline
\end{tabular}

Dalam 3 tahun

terakhir,kehadiran

dalam mengikuti pelatihan yang

berhubungan

dengan pendidikan

berkelanjutan

tentang apotek

Belum pernah

Satu kali

2-3 kali

2

$40 \%$

$>3$ kali

3

$60 \%$

Apakah apoteker

sudah mengetahui

tentang Keputusan

Menteri Kesehatan

Republik Indonesia

No 73 Tahun 2016

tentang standar

pelayanan

kefarmasian

Ya

Tidak

$5 \quad 100 \%$

Berdasarkan data hasil pengisian kuesioner dapat diketahui bahwa sebagian besar apoteker yang ada di apotek BUMN wilayah kota Manado mempunyai pengalaman sebagai APA (Apoteker Pengelola Apotek) selama 1-5 tahun sebesar $80 \%$ (Tabel 3). Semakin lama pengalaman apoteker sebagai Apoteker Pengelola Apotek maka semakin banyak pengalaman dan ilmu yang didapatkan sehingga apoteker tersebut dapat memberikan pelayanan yang baik dan berkualitas terhadap konsumen.

Hasil penelitian terkait frekuensi kehadiran apoteker pada ke 5 apotek milik BUMN di kota Manado diketahui bahwa mayoritas frekuensi kehadiran Apoteker Pengelola Apotek (APA) sebesar 80\%, dengan rata-rata diatas 5 jam perhari. Ketidakhadiran Apoteker Pengelola Apotek (APA) di apotek akan digantikan oleh apoteker pendamping, dimana terdapat 2 
apotek yang telah memiliki apoteker pendamping sedangkan 3 apotek tidak memiliki apoteker pendamping. Kehadiran Apoteker Pengelola Apotek selama apotek beroperasi merupakan hal yang harus dipenuhi sesuai dengan standar pelayanan kefarmasian di apotek.

Hasil penelitian pada Tabel 4, diketahui frekuensi kehadiran apoteker dalam pelatihan selama 3 tahun terakhir. Apoteker yang mengikuti pelatihan 2-3 kali sebanyak 2 apotek dan apoteker yang mengikuti $>3$ kali sebanyak 3 apotek. Semakin banyak frekuensi kehadiran apoteker dalam pelatihan-pelatihan dan pembinaan yang berhubung dengan pendidikan berkelanjutan tentang apotek yang diselenggarakan oleh Dinas Kesehatan dan Ikatan Apoteker Indonesia, semakin banyak pengetahuan baru yang di dapatkan tentang perapotekan, pelayanan, kesehatan, penyakit dan pengobatannya. Apoteker yang berada di apotek BUMN wilayah kota Manado sebesar $100 \%$ mengetahui tentang Peraturan Menteri Kesehatan Republik Indonesia Nomor 73 Tahun 2016 tentang Standar Pelayanan Kefarmasian di Apotek. Hal ini juga berkaitan dengan pembinaan yang diberikan oleh dinas kesehatan dan organisasi lain karena sebagian besar mendapat pembinaan dari keduanya.

Data Pengelolaan Sumber Daya

Tabel 3. Data Pengelolaan Sumber Daya dan Ketersediaan Fasilitas Sarana dan Prasarana

\begin{tabular}{lcc}
\hline Keterangan & $\begin{array}{c}\text { Jumlah } \\
\text { Apotek }\end{array}$ & $\begin{array}{c}\text { Presentas } \\
\text { e }\end{array}$ \\
\hline Apoteker mampu & 5 & $100 \%$ \\
menyediakan dan & & \\
memberikan & & \\
pelayanan yang & & \\
baik & & \\
\hline
\end{tabular}

Terdapat papan
petunjuk yang

Apotek terjaga

$100 \%$

kebersihannya

Apotek

5

$100 \%$

mempunyai ruang

tunggu yang

nyaman

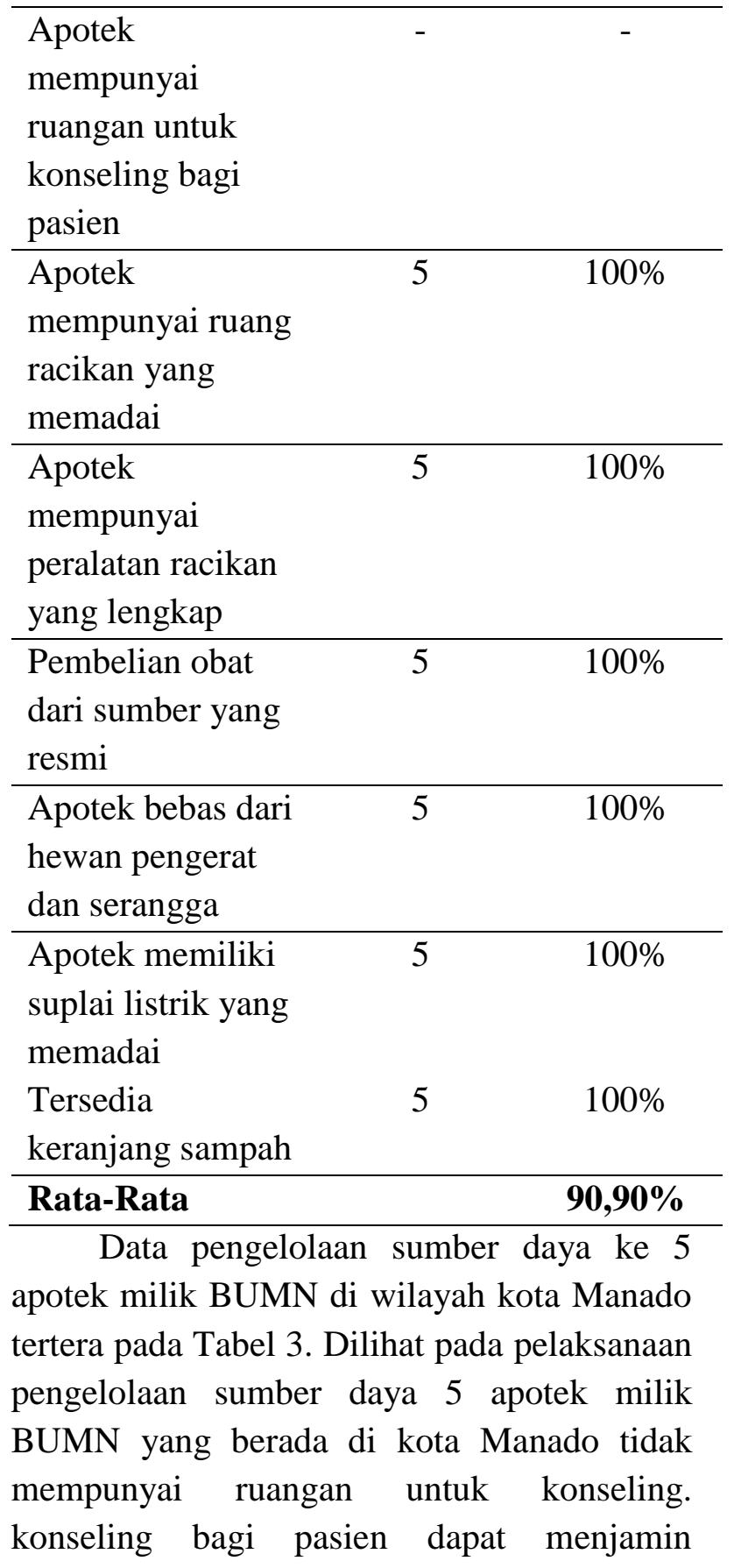


keamanan dan efektifitas pengobatan, mendapatkan penjelasan tambahan mengenai penyakitnya, menurunkan kesalahan penggunaan obat, dapat menghindari reaksi obat yang tidak diinginkan dan salah satu manfaat bagi apotek untuk menarik pelanggan sehingga menjadi upaya dalam memasarkan jasa pelayanan (Anief, 2001).

Lingkungan apotek harus terjaga kebersihannya, salah satunya dengan menyediakan prasarana kebersihan seperti tempat sampah, terbebas dari hewan pengerat dan serangga yang dapat merusak kualitas obat serta apotek harus memiliki suplai listrik yang memadai. Dalam sebuah apotek diperlukan ruang tunggu bagi pasien yang digunakan oleh pasien untuk menunggu obat yang sedang diracik. Adanya ruang tunggu yang memadai, membuat pasien merasa nyaman. Untuk membuat racikan obat yang baik diperlukan juga ruang racikan dan peralatan racik yang lengkap. Data yang diperoleh dari 5 apotek diketahui bahwa apotek memiliki ruang racik telah memiliki ruang racik yang sesuai dan mempunyai peralatan racik yang lengkap.

Tabel 4. Data Pengelolaan Perbekalan

\begin{tabular}{lcc}
\hline Keterangan & $\begin{array}{c}\text { Jumlah } \\
\text { Apotek }\end{array}$ & Presentase \\
\hline $\begin{array}{l}\text { Pendistribusian } \\
\text { perbekalan }\end{array}$ & 5 & $100 \%$ \\
farmasi & & \\
berdasarkan & & \\
sistem FIFO & & \\
(First In First & & \\
Out) & & \\
\hline $\begin{array}{l}\text { Pendistribusian } \\
\text { perbekalan }\end{array}$ & 5 & $100 \%$ \\
farmasi & & \\
berdasarkan & & \\
sistem FEFO & & \\
(First Expire & & \\
First Out) & & \\
\hline
\end{tabular}

\begin{tabular}{lll}
\hline $\begin{array}{l}\text { Penyimpanan } \\
\text { perbekalan } \\
\text { farmasi sesuai } \\
\text { kondisi yang di } \\
\text { persyaratkan }\end{array}$ & 5 & $100 \%$ \\
\hline $\begin{array}{l}\text { Obat/bahan obat } \\
\text { disimpan dalam } \\
\text { wadah asli dari } \\
\text { pabrik }\end{array}$ & 5 & $100 \%$ \\
\hline $\begin{array}{l}\text { Penyimpanan } \\
\text { Obat Golongan } \\
\text { psikotropika dan } \\
\text { obat golongan } \\
\text { narkotika pada } \\
\text { lemari tersendiri }\end{array}$ & 5 & $100 \%$ \\
\hline $\begin{array}{l}\text { Ada pencatatan } \\
\text { untuk masa }\end{array}$ & & \\
kadaluarsa & 5 & $100 \%$ \\
\hline $\begin{array}{l}\text { Dilakukan } \\
\text { penyimpanan } \\
\text { resep sesuai } \\
\text { ketentuan }\end{array}$ & & \\
\hline $\begin{array}{l}\text { Ada pencatatan } \\
\text { obat golongan } \\
\text { psikotropika }\end{array}$ & 5 & $100 \%$ \\
\hline $\begin{array}{l}\text { Ada pencatatan } \\
\text { obat golongan } \\
\text { narkotika }\end{array}$ & & \\
\hline Rata-Rata & 5 & $100 \%$ \\
\hline & & \\
\hline & & \\
\hline
\end{tabular}

Dalam Permenkes No. 73 Tahun 2016 tentang Standar Pelayanan Kefarmasian bahwa pengelolan persediaan farmasi dan perbekalan kesehatan, meliputi perencanaan, pengadaan, penerimaan, penyimpanan, dan pelayanan di apotek BUMN menggunakan sistem penyimpanan FIFO dan FEFO. Sistem FIFO merupakan penyimpanan obat berdasarkan obat yang datang lebih dulu dan dikeluarkan lebih dulu dan sistem FEFO merupakan penyimpanan obat berdasarkan obat yang memiliki tanggal kadaluarsa lebih cepat maka dikeluarkan lebih dulu. Kedua sistem ini 
dimaksudkan untuk menghindari obat-obat yang kadaluarsa.

Penyimpanan perbekalan farmasi disesuaikan dengan kondisi yang dipersyaratkan, terlindungi dari debu, kelembaban dan cahaya yang berlebihan serta diletakkan pada kondisi ruangan dengan temperatur yang telah ditetapkan. Obat/ bahan obat ini harus disimpan dalam wadah asli dari pabrik. Dalam hal pengecualian atau darurat dimana isi dipindahkan pada wadah lain, maka harus dicegah terjadinya kontaminasi dan harus ditulis informasi yang jelas pada wadah baru, wadah sekurang-kurangnya memuat nama obat, nomor batch, dan tanggal kadaluarsa (Permenkes RI, 2016). Apotek yang menyimpan golongan obat narkotika pada lemari khusus sebanyak 5 apotek. Pencatatan masa kadaluarsa obat sebanyak 5 apotek. Pencatatan ini sangat penting karena untuk mengetahui obat yang mendekati waktu kadaluarsa yang dapat berpengaruh terhadap khasiat dan efek obat. Penyimpanan resep sebanyak 5 apotek diurutkan sesuai tanggal dan nomor pemeriksaan.

Hasil penelitian diatas diketahui bahwa 5 apotek milik BUMN di wilayah kota Manado telah melaksanakan pengelolaan sumber daya yang sesuai dengan standar sebesar 5 apotek dengan persentase sebesar

$100 \%$, dengan telaksananya pengelolaan sumber daya yang sesuai standar maka dapat menunjang terlaksananya pelayanan sesuai dengan Permenkes Menteri Kesehatan No. 73 Tahun 2016.
Tabel 5. Perolehan Persentase pengelolaan Perbekalan, Sumber Daya dan Ketersediaan Fasilitas Sarana dan Prasarana

\begin{tabular}{lcc}
\hline $\begin{array}{l}\text { Nama } \\
\text { Apotek }\end{array}$ & Persentase & Kategori \\
\hline Apotek A & $100 \%$ & Baik \\
Apotek B & $100 \%$ & Baik \\
Apotek C & $100 \%$ & Baik \\
Apotek D & $100 \%$ & Baik \\
Apotek E & $100 \%$ & Baik \\
\hline
\end{tabular}

Berdasarkan Tabel 5 dapat diketahui bahwa 5 apotek milik BUMN wilayah kota Manado termasuk dalam kategori baik karena telah memperoleh persentase $\geq 75 \%$. 


\begin{tabular}{|c|c|c|}
\hline Keterangan & Jumlah & $\begin{array}{c}\text { Presenta } \\
\text { se }\end{array}$ \\
\hline $\begin{array}{l}\text { Terdapat Standar } \\
\text { Operating Procedure } \\
\text { pelayanan obat }\end{array}$ & 5 & $100 \%$ \\
\hline $\begin{array}{l}\text { Resep diskrining } \\
\text { administratif resep } \\
\text { terlebih dahulu sebelum } \\
\text { dilayani }\end{array}$ & 5 & $100 \%$ \\
\hline $\begin{array}{l}\text { Resep dinilai kesesuaian } \\
\text { farmasetik } \\
\text { (dosis,inkompatibilitas, } \\
\text { bentuk sediaan) pada } \\
\text { resep }\end{array}$ & 5 & $100 \%$ \\
\hline $\begin{array}{l}\text { Obat dikemas dengan } \\
\text { etiket yang jelas tentang } \\
\text { cara pakai obat }\end{array}$ & 5 & $100 \%$ \\
\hline $\begin{array}{l}\text { Apoteker melakukan } \\
\text { pengecekan akhir } \\
\text { terhadap kesesuaian } \\
\text { antara resep dan obat }\end{array}$ & 5 & $100 \%$ \\
\hline $\begin{array}{l}\text { Penyerahan obat } \\
\text { dilakukan oleh apoteker }\end{array}$ & 2 & $40 \%$ \\
\hline $\begin{array}{l}\text { Saat penyerahan obat } \\
\text { disertai pemberian } \\
\text { informasi obat dan } \\
\text { konseling pada pasien }\end{array}$ & 5 & $100 \%$ \\
\hline $\begin{array}{l}\text { Disediakan waktu } \\
\text { khusus bagi pasien yang } \\
\text { terjadwal untuk } \\
\text { konsultasi dengan } \\
\text { apoteker }\end{array}$ & - & - \\
\hline $\begin{array}{l}\text { Apoteker mengikuti } \\
\text { perkembangan ilmu } \\
\text { pengetahuan untuk } \\
\text { meningkatkan mutu } \\
\text { pelayanan kefarmasian }\end{array}$ & 5 & $100 \%$ \\
\hline
\end{tabular}

\section{Data Pelayanan}

Tabel 6. Data Pelaksanaan Pelayanan Resep

\begin{tabular}{lll}
\hline $\begin{array}{l}\text { Apotek pernah } \\
\text { melakukan survei }\end{array}$ & - & - \\
tingkat kepuasan pasien & & \\
\hline $\begin{array}{l}\text { Apoteker memberikan } \\
\text { pelayanan berupa }\end{array}$ & 3 & $60 \%$ \\
kunjungan rumah & & \\
$($ Home care $)$ & & \\
\hline
\end{tabular}

Rata-Rata $\mathbf{7 2 , 7 2 \%}$

Pelayanan kefarmasian yang baik dan memenuhi standar di apotek merupakan salah satu upaya dalam meningkatkan kualitas mutu dan kemajuan apotek. Hal ini didukung dengan memberikan pelayanan yang baik pada konsumen serta untuk menjamin tercapainya penggunaan obat yang aman dan tepat sehingga terapi terpenuhi. Upaya ini dilakukan berdasarkan dengan Peraturan Menteri Kesehatan No. 73 Tahun 2016 tentang Standar Pelayanan Kefarmasian di Apotek.

Penyiapan obat yang meliputi peracikan, penulisan etiket, dan pengemasan obat, harus sesuai dengan Standar Operasional Prosedur (SOP). Peracikan obat harus sesuai dengan prosedur dengan memperhatikan dosis, jenis dan jumlah obat serta penulisan etiket yang benar. Apotek yang mempunyai SOP sebanyak 5 apotek. Apotek yang melakukan skrining resep sebanyak 5 apotek. Skrining resep bertujuan untuk menghindari adanya kekeliuran pada resep seperti ketidaksesuaian dosis, interaksi obat, inkompatibilitas. Hal ini dilakukan sebelum resep dari dokter diracik. Skrining resep meliputi skrining administratif, kesesuaian farmasetik dan pertimbangan klinis. Apotek yang melakukan penilaian farmasetik pada resep sebanyak 5 apotek. Ke 5 Apotek juga melakukan pengemasan dengan etiket yang jelas tentang cara pakai obat, setelah obat 
selesai diracik dan dilakukan pemeriksaan akhir antara kesesuaian obat dengan resep.

Penyerahan obat oleh apoteker harus memberikan informasi yang jelas, dan mudah dimengerti. Pemberian informasi obat merupakan kegiatan penyediaan dan memberikan informasi yang indenpenden, akurat, komperhensif, terkini oleh apoteker kepada pasien, masyarakat maupun pihak yang memerlukan. Informasi obat pada pasien sekurang-kurangnya meliputi cara pemakaian obat, cara penyimpanan obat (Widy, 20011). Menurut Departemen Kesehatan Tahun 2003 tentang Pelayanan Farmasi, Standar kompetensi apoteker di apotek dimaksudkan untuk melindungi masyarakat dari pelayanan yang tidak profesional, melindungi profesi dari tuntutan masyarakat yang tidak wajar dan untuk meningkatkan mutu pelayanan farmasi di apotek. Apoteker yang pada saat penyerahan obat memberikan informasi pada pasien sebanyak 2 apotek. Hal ini karena frekuensi dan lama kehadiran apoteker di apotek yang tidak menentu dan kurangnya tenaga apoteker.

Standar Pelayanan Kefarmasian di Apotek menurut Permenkes No.73 Tahun 2016 bahwa apoteker harus memberikan konseling mengenai sediaan farmasi, pengobatan dan perbekalan kesehatan lainnya, sehingga dapat memperbaiki kualitas hidup pasien terhindar dari bahaya penyalahgunaan atau penggunaan sediaan farmasi atau perbekalan kesehatan lainnya (Permenkes, 2016).

Konseling ini merupakan sarana bagi apoteker untuk membantu pasien mengatasi masalah pengobatan yang sedang mereka jalani. Melalui konseling, apoteker dapat melakukan penilaian terhadap pemahaman pasien baik terhadap penyakit maupun obat yang sedang mereka gunakan (Kooij, dkk 2016).
Berdasarkan uraian diatas maka diperlukan waktu khusus bagi pasien yang terjadwal untuk konsultasi dengan apoteker. Tetapi Data pada Tabel 6 menunjukkan bahwa tidak ada apotek yang menyediakan waktu khusus yang terjadwal. Hal tersebut dikarenakan sebagian besar apoteker tidak memiliki waktu yang memadai. Tujuan kegiatan ini yaitu untuk memaksimalkan pelayanan terhadap agar tercapai kesehatan masyarakat yang optimal. Indikator yang digunakan untuk mengevaluasi baik atau tidaknya mutu pelayanan yang diberikan apotek kepada masyarakat tergantung dari penilaian masyarakat itu sendiri yaitu dengan survei tingkat kepuasan konsumen dengan menggunakan angket. Apotek milik BUMN wilayah kota Manado belum pernah melakukan survei tingkat kepuasan pelayanan kefarmasian di apotek. Apoteker sebagai care giver diharapkan juga dapat melakukan pelayanan kefarmasian yang bersifat kunjungan rumah, khususnya untuk kelompok lansia dan pasien dengan pengobatan penyakit kronis lainnya, apoteker yang memberikan pelayanan berupa kunjungan rumah (Home Care) sebesar $60 \%$.

Tabel 7. Perolehan Persentase Pelaksanaan Pelayanan Resep

Nama Persentase Kategori

Apotek

\begin{tabular}{llc}
\hline Apotek A & $81,81 \%$ & Baik \\
Apotek B & $81,81 \%$ & Baik \\
Apotek C & $72,72 \%$ & Cukup \\
Apotek D & $63,63 \%$ & Cukup \\
Apotek E & $63,63 \%$ & Cukup \\
\hline
\end{tabular}


Berdasarkan Tabel 7 dapat diketahui bahwa 5 apotek BUMN di Kota Manado terdapat 2 apotek dalam kategori baik dan terdapat 3 apotek dalam kategori cukup. Hal tersebut dapat disebabkan karena apotek tidak menyediakan waktu konsultasi untuk pasien dengan apoteker, belum melakukan survei tingkat kepuasan konsumen dan kurangnya pelayanan kefarmasian yang bersifat kunjungan ruma (Home Care).

\section{KESIMPULAN}

Berdasarkan hasil penelitian yang telah dilakukan di 5 apotek BUMN wilayah kota Manado diperoleh hasil pelaksanaan standar pelayanan kefarmasian di apotek ditinjau dari aspek pengelolaan perbekalan, sumber daya dan ketersediaan fasilitas sarana dan prasarana dapat diketahui berdasarkan perhitungan yang dianalisis secara deskriptif masuk dalam kategori baik dengan jumlah 5 apotek dan pelaksanaan standar pelayanan kefarmasian di apotek ditinjau dari aspek pelayanan resep dapat diketahui berdasarkan hasil perhitungan yang dianalisis deskriptif masuk dalam kategori baik dengan jumlah 2 apotek.

\section{SARAN}

Diharapkan dapat melakukan penelitian di Apotek yang berada di Wilayah kota Manado.

\section{DAFTAR PUSTAKA}

Anief, M. 2001. Manajemen Farmasi. Yogyakarta : UGM Press.

Arikunto, M. 2001. Manajemen Farmasi. Yogyakarta : UGM Press.

Hartini, S.Y. 2006. Sebuah Potret Pelaksanaan Kefarmasian di Apotek. Jakarta : PT.ISFI.
Kooij, MJ., Heerdink, R,. 2016. Konseling Farmasi. Jurnal Phamacon. Jakarta

Maryati, D. 2013.Evaluasi Standar Pelayanan Kefarmasian di Apotek Wilayah Kota Salatiga Sesuai Perundangan yang Berlaku, [Skripsi]. Fakultas Farmasi,Universitas Muhammadiyah, Solo.

Notoatmodjo. 2002. Metedologi Penelitian Kesehatan. PT. Rineka Cipta: Jakarta.

Peraturan Menteri Kesehatan RI. 2016. Standar Pelayanan Kefarmasian di Apotek. Jakarta.

Situmorang, C.H. 2000. Pedoman Pelayanan Rumah Sakit. Persfektif Profesi Farmasis (Apoteker) Menuju Paradigma Baru Pelayanan Kefarmasian. Jakarta : CCED Pharma Foundation.

Widysusanti, A. 2011. Gambaran Pelaksanaan Pelayanan Informasi Obat Bagi Pasien Pengguna Produk Antasida Di Apotek Kota Gorontalo. (Jurnal Farmasi). Gorontalo : UNG. 